\title{
Endometrial tumor necrosis factor $\alpha$ (TNF $\alpha)$ is a likely mediator of early luteal phase mifepristone-mediated negative effector action on the preimplantation embryo
}

\author{
PGL Lalitkumar, J Sengupta and D Ghosh \\ Department of Physiology, All India Institute of Medical Sciences, New Delhi-110029, India \\ Correspondence should be addressed to D Ghosh; Email: dghosh@aiims.ac.in
}

\begin{abstract}
Cytokines and growth factors are important mediators of progesterone-regulated endometrial receptivity and embryo development. Early luteal phase administration of a potent antiprogestin-like mifepristone to the rhesus monkey results in endometrial desynchrony, loss of embryo viability and implantation failure. In the present study, administration of mifepristone $(2 \mathrm{mg} / \mathrm{kg}$ body weight, s.c.) on day 2 after ovulation resulted in a significant increase $(P<0.01)$ in the level of tumor necrosis factor $\alpha$ (TNF $\alpha$ ) in glandular and vascular compartments of endometrium, and in endometrial secretion and luminal fluid on day 6 after ovulation in the rhesus monkey. There was an associated lag in embryonic development, characterized by delayed mitochondrial maturity, poorly developed junctional complexes, a relative absence of intra-cytoplasmic filaments and a high degree of intra-cellular degenerative features. Exposure of TNF $\alpha(0,0.5,5,50 \mathrm{ng} / \mathrm{ml})$ to preimplantation stage mouse embryos in vitro showed a dose-dependent arrest in growth and development at both morula and blastocyst stages along with ultrastructural features of degeneration similar to those observed in embryos collected from early luteal phase mifepristone-treated monkeys. The de novo synthesized and released proteins in terms of trichloroacetic acid precipitable ${ }^{35} \mathrm{~S}$ by morulae and blastocysts in vitro showed a marked depression following exposure to TNF $\alpha$ compared with control embryos. Based on the above observation and the fact that preimplantation stage embryos express receptors for TNF $\alpha$, we suggest that increased levels of TNF $\alpha$ in endometrial and luminal compartments around the time of uterine receptivity following early luteal phase administration of mifepristone adversely affect the growth and viability of preimplantation stage embryos.

Reproduction (2005) 129 323-335
\end{abstract}

\section{Introduction}

The viability and growth of preimplantation embryos, as well as implantation of blastocysts, are regulated by a complex network of autocrine and paracrine processes involving a large number of factors (Edwards 1995, Polan et al. 1995, Tabibzadeh \& Babaknia 1995, Ghosh \& Sengupta 1998). Progesterone is essential for endometrial preparation for blastocyst implantation (Ghosh \& Sengupta 1998). We have demonstrated previously in the rhesus monkey that a potent antiprogestin-like mifepristone inhibits blastocyst implantation (Ghosh \& Sengupta 1993) because the endometrium becomes desynchronized following early luteal phase mifepristone treatment in this species (Ghosh et al. 1996, Sengupta \& Ghosh 2000). We have also demonstrated that early luteal phase exposure to mifepristone inhibits the morula-to-blastocyst transition as well as the viability of blastocysts in the rhesus monkey (Ghosh et al. 1997, Ghosh et al. 2000). We hypothesize that inhibition of progesterone action in the endometrium alters the profiles of cytokines in endometrium and luminal milieu that in turn affects embryonic growth and viability during the preimplantation stage of gestation. Among the various principal cytokines which may reportedly be involved in these processes, tumor necrosis factor $\alpha$ (TNF $\alpha$ ) appears to be a strong candidate (Ghosh \& Sengupta 1998). Progesterone inhibits TNF $\alpha$ synthesis and secretion in endometrium (von Wolff et al. 1999). TNF $\alpha$ appears to be inhibitory to the viability, growth and differentiation of preimplantation stage blastocysts (Hill et al. 1987, Pampfer et al. 1994a,b, Wuu et al. 1999, Ben-yair et al. 1997, Kurzawa et al. 2001). However, human embryos secrete TNF $\alpha$ in vitro until morula stage, but not at blastocyst stage (Lachapelle et al. 1993). Thus, it is not known whether TNF $\alpha$ can specifically influence morulato-blastocyst transition and blastocyst differentiation. In the present study, we have examined this question by investigating: (i) the levels of synthesis and secretion of $\mathrm{TNF} \alpha$ by implantation stage endometrium, as well as the morphological characteristics of preimplantation stage 
embryos following early luteal phase mifepristone treatment to rhesus monkeys, and (ii) the effect of TNF $\alpha$ on the functional and developmental characteristics of mouse morulae and blastocysts following their in vitro exposure to $T N F \alpha$. Mouse embryos were used in the second part of the study because of the ethical and practical constraints in the use of monkey embryos. Our results lend support to the proposed hypothesis that endometrial and luminal levels of TNF $\alpha$ increase around the time of uterine receptivity following early luteal phase mifepristone action in the rhesus monkey and that TNF $\alpha$ adversely affects the growth and viability of preimplantation stage embryos.

\section{Materials and Methods \\ Experiments using monkeys}

\section{General procedures and treatment groups}

Healthy, mature and proven fertile male and female rhesus monkeys (Macaca mulatta) that were kept in a semi-natural condition at the Primate Research Facility of the All India Institute of Medical Sciences (New Delhi, India) were used in this study. The details of animal selection, housing, management, monitoring of cycles, mating, laparotomy, endometrial sampling, serum collection and radioimmunoassay for serum estradiol-17 $\beta$ and progesterone have been described elsewhere (Ghosh \& Sengupta 1993, Ghosh et al. 1996, Ghosh et al. 1997, Ghosh et al. 2000, Sengupta \& Ghosh 2000). The study design was approved by the Ethics Committee for the Use of Van-human Primates in Biomedical Research of the All India Institute of Medical Sciences.

Female monkeys showing at least two consecutive ovulatory menstrual cycles of normal length (26-32 days) were allocated to two groups. Animals $(n=25)$ were allowed to cohabit with males during days $8-16$ of their menstrual cycles. Vaginal smears were checked daily for the presence of spermatozoa. Female monkeys of group 1 were injected s.c. with $2 \mathrm{ml}$ vehicle $(1: 4$, benzyl benzoate:olive oil, $\mathrm{v} / \mathrm{v} ; n=10$ ) only and animals of group 2 were injected s.c. a single dose of mifepristone $(2 \mathrm{mg} / \mathrm{kg}$ body weight; $n=15$ ) in the same volume of vehicle on day 2 after ovulation in mated cycles. In groups 1 and 2, endometrial samples were collected on day 6 after ovulation and samples only from mated, ovulatory cycles that yielded preimplantation stage embryos were used for further examination in this study. Recovered embryos were assessed for their developmental status under stereo-zoom microscope as described earlier (Ghosh et al. 2000). After retrieval of the embryo, the uterine fluid was kept at $-70^{\circ} \mathrm{C}$ for subsequent estimation of TNF $\alpha$ concentration by enzyme immunoassay as described below. Table 1 shows the details of the embryos recovered from both groups on day 6 after ovulation. The days of ovulation in both groups were assessed from the profiles of estradiol-17 $\beta$ and progesterone in peripheral serum samples. Steroid radioimmunoassays were performed using antisera and reagents obtained from the World Health Organization Matched Reagent Programme. The methodological details are described elsewhere (Ghosh \& Sengupta 1993, Ghosh et al. 1996, Ghosh et al. 1997, Ghosh et al. 2000, Sengupta \& Ghosh 2000).

\section{Tissue collection and processing}

The procedural details of collection and processing of endometrial samples for Western immunoblotting and immunohistochemistry have been described elsewhere (Ghosh et al. 1996, Sengupta \& Ghosh 2000). Briefly, endometrial samples were collected on day 6 after ovulation from animals of group $1(n=6)$ and group 2 $(n=7)$ by performing laparotomy and fundal hysterotomy following ketamine $(12 \mathrm{mg} / \mathrm{kg}$; Vetlar, Parke-Davis, Mumbai, India) anaesthesia. For immunohistochemistry, the tissue samples were quickly washed in ice-cold phosphate buffered saline and then fixed in phosphate buffered neutral paraformaldehyde $(4 \%, \mathrm{w} / \mathrm{v})$ and finally embedded in paraffin wax by a routine procedure. Furthermore, tissue samples were also homogenized in TE buffer $(10 \mathrm{mM}$ Tris, $1 \mathrm{mM}$ EDTA, pH 8.0) with $1 \mathrm{mM}$ phenyl methyl sulphonyl fluoride (PMSF). Additionally, tissue samples were also processed for incubation in phenol red free Eagle's minimum essential medium for $16 \mathrm{~h}$ at $37^{\circ} \mathrm{C}$ in a humidified environment of $5 \%$ carbon dioxide and $95 \%$ air. Tissue homogenates and spent media were used for dot blot and western blot analysis. All chemicals were purchased from Sigma Chemical Co. (St. Louis MO, USA).

\section{Immunoblot, enzyme immunoassay and immunohistochemistry}

Profiles of TNF $\alpha$ in tissue spent media were characterized by the SDS-PAGE/western immunoblotting method as described elsewhere (Ghosh et al. 1998) using electrophoresis and trans-blot equipment from Bio-Rad (Hercules CA, USA), and the materials and chemicals

Table 1 Preimplantation embryos recovered on day 6 after ovulation ${ }^{\mathrm{a}}$ in monkeys with or without mifepristone treatment on day 2 after ovulation $^{\mathrm{a}}$

\begin{tabular}{|c|c|c|c|c|c|c|}
\hline \multirow[b]{2}{*}{ Group } & \multirow[b]{2}{*}{ Number of ovulatory cycles } & \multicolumn{5}{|c|}{ Number of embryos recovered } \\
\hline & & Degenerated/desynchronized & Morula & Early blastocyst & Blastocyst & Total \\
\hline 1 (vehicle only) & 10 & 1 & 0 & $1^{\mathrm{b}}$ & $4^{b}$ & 6 \\
\hline 2 (mifepristone, $2 \mathrm{mg} / \mathrm{kg}$ ) & 15 & 2 & $4^{\mathrm{b}}$ & 0 & $1^{\mathrm{b}}$ & 7 \\
\hline
\end{tabular}

Day of ovulation, ${ }^{\mathrm{a}} 24 \mathrm{~h}$ after preovulatory estradiol rise in peripheral circulation. ${ }^{\mathrm{b}}$ embryos used in ultrastructural study. 
were purchased from Bio-Rad Laboratories and Sigma Chemical Company. Samples of $25 \mu \mathrm{g}$ protein content and pre-stained molecular weight markers (Amersham Pharmacia Biotech, Amersham, UK) were separated on 15\% SDS-PAGE gels and transferred to nitrocellulose membranes. After blocking the nonspecific binding, these membranes were then incubated with neutralizing antibody (R\&D Systems, Minneapolis, MN, USA) against TNF $\alpha$ at a working dilution of 1:1500 (stock: $1 \mathrm{mg} / \mathrm{ml}$ ). Final visualization was achieved by using Vectastain $A B C$ immunoperoxidase kits (Vector Laboratories, Burlingame, CA, USA). The molecular weights and semi-quantitative densitometric analysis of bands were determined using a Gel Scanner GS 670 and Molecular Analyst image analysis software (Bio-Rad). The results are shown as Mr of individual bands and semi-quantitative measures of integral optical density.

Endometrial tissue homogenate (10 $\mu$ g of protein) was also taken for dot blot study using nitrocellulose membrane. The blocking of the nonspecific binding, immunoliganding with antibody (R\&D Systems) against TNF $\alpha$ and final visualization was achieved using protocol as described above. Respective primary antibody control and secondary antibody control were run to examine the specificity of the procedure. Semi-quantitative estimates of integral optical density were recorded.

The concentrations of TNF $\alpha$ in uterine fluid collected from animals of group $1(n=6)$ and group $2(n=7)$ yielding embryos were determined by enzyme immunoassay using chemicals from R\&D Systems according to the protocol provided by the manufacturer and expressed in terms of total protein estimated by Bio-Rad protein assay reagent (Gogstad \& Krutness 1982).

$5 \mu \mathrm{m}$ paraffin sections were employed for immunohistochemical localization of TNF $\alpha$ using specific antibody (R\&D Systems) at a working dilution of $7.5 \mu \mathrm{g} / \mathrm{ml}$. Visualization was achieved using Vectastain $A B C$ Peroxidase Elite Kit (Vector Laboratories, Burlingame, USA) and 3,3'diaminobenzidine hydrochloride (Sigma Chemical Co.) and hydrogen peroxide following a method described previously (Ghosh et al. 1997). Respective primary antibody control and secondary antibody control were run simultaneously. Semi quantitative analysis of the area of immunoprecipitation for $\mathrm{TNF} \alpha$ on the endometrial sections was done using computer aided image analysis (Quantimet $\mathrm{C}+$, Leica, Germany) as described earlier (Ghosh et al. 1998).

The specificity of the antibody binding in western blot and immunohistochemistry was checked by immunoneutralization using recombinant human TNF $\alpha$ (R\&D Systems) as described previously (Ho et al. 1999).

\section{Detection of TNF-Receptor I (TNF-RI) in monkey blastocysts}

Two blastocyst stage embryos were recovered from mated rhesus monkeys on day 6 after ovulation, as described above, and were fixed in $4 \%$ paraformaldehyde in $0.1 \mathrm{~mol} / \mathrm{l}$ phosphate buffer $(\mathrm{pH} 7.2)$ and washed in cold phosphate buffer followed by dehydration in graded alcohol and embedded in London Resin (LR) white (Electron Microscopy Sciences, Fort Washington, PA, USA). Semithin $(1 \mu \mathrm{m})$ sections were cut and stained with toluidine blue as detailed previously (Ghosh et al. 1996). Prior to immunohistochemical localization of TNF-R1, the endogenous peroxidase in the embryo sections were quenched with $0.3 \%$ hydrogen peroxide following the unmasking of antigens with $0.125 \%(\mathrm{w} / \mathrm{v})$ trypsin for $10 \mathrm{~min}$. After washing the sections in phosphate buffered saline $(\mathrm{pH} 7.2)$, the sections were blocked with $2 \%(\mathrm{v} / \mathrm{v})$ goat serum and exposed to anti-rabbit polyclonal antibody against hTNF-RI (Santa Cruz biotechnology, Santa Cruz, CA, USA) at $4{ }^{\circ} \mathrm{C}$ overnight. Subsequent visualization steps were performed using Vectastain Elite $\mathrm{ABC}$ kit and enhancing solution (Vector Laboratories).

\section{Experiments using mice}

\section{Mouse embryo collection and culture}

Random-bred sexually mature Swiss albino female mice were subjected to superovulation and allowed to mate with adult males using standardized protocol (Hogan et al. 1994). Day 1 of pregnancy was designated from the day of detection of copulatory plug. Uterine horns were flushed with M2 medium ( $\mathrm{pH}$ 7.4) on the morning of day 4 (Pratt 1987). Morulae and blastocysts with normal appearance under phase contrast microscope were collected and used in different experiments as described below.

Medium M16 (pH 7.6) supplemented with sodium pyruvate $(36 \mu \mathrm{g} \mathrm{w} / \mathrm{v})$, bovine serum albumin $(0.4 \% \mathrm{w} / \mathrm{v})$ along with different concentrations $(0,0.5,5$ and $50 \mathrm{ng} / \mathrm{ml})$ of $\mathrm{TNF} \alpha$ (R\&D Systems) was used at a ratio of $50 \mu \mathrm{l} / \mathrm{embryo}$ to culture morulae (group I) and blastocysts (group II) taken in randomly assigned pool of four embryos in humidified $5 \%$ carbon dioxide in air at $37^{\circ} \mathrm{C}$ (Pratt 1987). Cultures were terminated at $24 \mathrm{~h}$ because the half-life of TNF $\alpha$ is about $30 \mathrm{~h}$ in culture medium (Wincek et al. 1991). The study design had been approved by the Institutional Animal Ethics Committee of AlIMS. Tables 2 and 3 show the details of different groups used in this experiment.

\section{Developmental status of cultured mouse embryos}

After $24 \mathrm{~h}$ culture, embryos were used to examine developmental status under light microscope. Tables 2 and 3 show the number of embryos in group I (morulae) and group II (blastocyst) used and the parameters examined to assess developmental status in this experiment.

\section{Protein synthesis by mouse embryos}

In order to examine the protein synthetic ability of morulae (group I) and blastocysts (group II) with or without $\mathrm{TNF} \alpha$ (0.5, $5.0,50.0 \mathrm{ng} / \mathrm{ml})$ in vitro, embryos $(\sim 100$ 
Table 2 Developmental status of mouse morulae cultured for $24 \mathrm{~h}$ in presence of TNF $\alpha$.

\begin{tabular}{|c|c|c|c|c|c|}
\hline \multirow[b]{2}{*}{ Group } & \multirow[b]{2}{*}{ Dose of TNF $\alpha(\mathrm{ng} / \mathrm{ml})$} & \multirow[b]{2}{*}{ Total number of experiments } & \multicolumn{3}{|c|}{ Developmental status (Total nmber, \%) } \\
\hline & & & Blastocyst & Arrested & Degenerated \\
\hline la & 0.0 & $50(6)$ & $41(82 \%)$ & $4(8 \%)$ & $5(10 \%)$ \\
\hline lb & 0.5 & $46(5)$ & $32(70 \%)$ & $2(4 \%)$ & $12(26 \%)^{1}$ \\
\hline IC & 5.0 & $52(6)$ & $15(29 \%)^{3}$ & $15(29 \%)^{3}$ & $22(42 \%)^{2}$ \\
\hline Id & 50.0 & $72(6)$ & $15(21 \%)^{3}$ & $19(26 \%)^{3}$ & $38(53 \%)^{3}$ \\
\hline
\end{tabular}

${ }^{1} P<0.05$ compared with la. ${ }^{2} P<0.01$ and ${ }^{3} P<0.001$ compared with la and $\mathrm{lb}$.

Table 3 Developmental status of mouse blastocysts cultured for $24 \mathrm{~h}$ in presence of TNF $\alpha$.

\begin{tabular}{lccccc}
\hline & & & \multicolumn{3}{c}{ Developmental status (Total number, \%) } \\
\cline { 3 - 6 } Group & Dose of TNF $\boldsymbol{\alpha}(\mathrm{ng} / \mathrm{ml})$ & Total number of experiments & Expanded blastocyst & Hatched blastocyst & Degenerated embryo \\
\hline Ila & 0.0 & $72(6)$ & $52(72 \%)$ & $16(22 \%)$ & $4(6 \%)$ \\
Ilb & 0.5 & $49(6)$ & $24(49 \%)^{1}$ & $12(25 \%)$ & $13(26 \%)^{2}$ \\
Ilc & 5.0 & $53(6)$ & $20(38 \%)^{3}$ & $15(28 \%)$ & $18(34 \%)^{3}$ \\
Ild & 50.0 & $70(6)$ & $20(28.5 \%)^{3,4}$ & $6(8.5 \%)^{3,4,6}$ & $44(63 \%)^{3,5,7}$ \\
\hline
\end{tabular}

${ }^{1} P<0.05,{ }^{2} P<0.01$ and ${ }^{3} P<0.001$ compared with group Ila. ${ }^{4} P<0.05$ and ${ }^{5} P<0.01$ compared with group Illb. ${ }^{6} P<0.01$ and ${ }^{7} P<0.05$ compared with group Ilc.

Table 4 Protein synthesis and release by mouse morulae and blastocysts with or without exposure to TNF $\alpha$ in vitro.

\begin{tabular}{|c|c|c|c|}
\hline Embryo stage & Treatment (Number of experiments) & Lysate $\left(\mathrm{cpm} \times 10^{-3} / \mathrm{embryo}\right)$ & Spent medium $\left(\mathrm{cpm} \times 10^{-3} / \mathrm{embryo}\right)$ \\
\hline \multirow[t]{4}{*}{ Morula } & Control (4) & $2.0 \pm 0.4$ & $6.7 \pm 0.9$ \\
\hline & $\mathrm{TNF} \alpha, 0.5 \mathrm{ng} / \mathrm{ml}(5)$ & $1.5 \pm 0.6$ & $3.6 \pm 0.8^{(* *)}$ \\
\hline & $\mathrm{TNF} \alpha, 5.0 \mathrm{ng} / \mathrm{ml}(5)$ & $1.2 \pm 0.5^{*}$ & $3.0 \pm 0.9^{(* *)}$ \\
\hline & $\mathrm{TNF} \alpha, 50.0 \mathrm{ng} / \mathrm{ml}(4)$ & $1.0 \pm 0.4 *$ & $1.8 \pm 0.7^{(* *)}$ \\
\hline \multirow[t]{4}{*}{ Blastocyst } & Control (4) & $3.1 \pm 0.7 *$ & $7.8 \pm 0.4^{(* *)}$ \\
\hline & $\mathrm{TNF} \alpha, 0.5 \mathrm{ng} / \mathrm{ml}(5)$ & $2.4 \pm 0.5^{(\mathrm{mlo} .5)}$ & $4.9 \pm 0.9^{(\mathrm{b}) /(\mathrm{msm0} 0.5)}$ \\
\hline & $\mathrm{TNF} \alpha, 5.0 \mathrm{ng} / \mathrm{ml}(4)$ & $1.8 \pm 0.4^{\mathrm{a} /(\mathrm{ml} 5.0)}$ & $4.2 \pm 0.6^{(\mathrm{b}) /(\mathrm{msm} \mathrm{5} 5.0)}$ \\
\hline & $\mathrm{TNF} \alpha, 50.0 \mathrm{ng} / \mathrm{ml}(5)$ & $1.3 \pm 0.3^{\mathrm{b} /(\mathrm{ml} 50)}$ & $4.0 \pm 0.4^{(\mathrm{b}) /(\mathrm{msm} 50)}$ \\
\hline
\end{tabular}

Values are shown as means \pm S.D. $* P<0.05$ compared with control morula lysate. ${ }^{\mathrm{a}} P<0.05$ and ${ }^{\mathrm{b}} P<0.01$ compared with control blastocyst lysate. ${ }^{(\mathrm{mlo} .5),(\mathrm{ml5} .0),(\mathrm{ml} 50)} P<0.05$ compared with morula lysates after treatment with $0.5 \mathrm{ng} / \mathrm{ml}, 5.0 \mathrm{ng} / \mathrm{ml}$ and $50.0 \mathrm{ng} / \mathrm{ml}$, respectively.

${ }^{(*)} P<0.05$ and ${ }^{(* *)} P<0.01$ compared with control morula spent medium. ${ }^{(b)} P<0.01$ compared with control blastocyst spent medium. (msm0.5), (msm5.0) $P<0.05$ compared with control morula spent medium after treatment with $0.5 \mathrm{ng} / \mathrm{ml}$, and $5.0 \mathrm{ng} / \mathrm{ml}$, respectively.

${ }^{[\mathrm{msm} 50]} P<0.01$ compared with control morula spent medium after treatment with $50.0 \mathrm{ng} / \mathrm{ml}$.

embryos per incubation) were cultured for $4 \mathrm{~h}$ in $\mathrm{M} 16$ medium (as described above) containing $100 \mu \mathrm{Ci} / \mathrm{ml}$ of ${ }^{35}$ S-methionine (Neider et al. 1987). Embryos were washed and lysed in sample buffer (SDS 0.30\% w/v, DTT $3.09 \% \mathrm{w} / \mathrm{v}$, Tris $-\mathrm{HCl} 0.44 \% \mathrm{w} / \mathrm{v}$, Tris base $0.27 \% \mathrm{w} / \mathrm{v}$ ) and spent media were also collected. Embryo lysates and media thus collected from 4-5 separate experiments, as shown in Table 4, were further analysed for the measurement of the TCA-precipitable ${ }^{35} \mathrm{~S}$ according to the procedure described by Nieder et al. (1987) in order to estimate the protein synthesis and release by morulae and blastocysts in vitro with or without TNF $\alpha$.

\section{Ultrastructure of monkey and mouse embryos}

Preimplantation embryos appearing normal under light microcope from both groups of monkeys (groups 1 and 2) and both groups of mice (groups I and II) were fixed in 3\% glutaraldehyde in $0.1 \mathrm{~mol} / \mathrm{l}$ phosphate buffer $(\mathrm{pH} 7.2)$, post-fixed in osmium tetroxide followed by dehydration in graded ethanol, and finally embedded in Spurr's resin.
Semithin $(0.5 \mu \mathrm{m})$ and thin $(70-80 \mathrm{~nm})$ sections were cut and examined as described previously (Ghosh et al. 2000).

\section{Statistical analysis}

Comparisons between groups for different parameters were performed using the Fisher's exact probability test, Student's $t$-test and analysis of variance followed by multiple comparison test as applicable (Zar 1999). Values are shown as means \pm S.D.

\section{Results}

\section{Developmental status of monkey preimplantation stage embryo on day 6 after ovulation following early luteal phase (day 2 after ovulation) administration of mifepristone}

As shown in Table 1, the rate of embryo recovery from mifepristone-treated monkeys (47\%) was less than that from the control group $(60 \%)$, however, this difference was not statistically significant. Analysis of developmental 
status revealed that $57 \%$ (four/seven) of recovered embryos from the mifepristone-treated monkeys (group 2) were morulae and $29 \%$ (two/seven) embryos were desynchronized or degenerated. On the other hand, 67\% (four/ six) of recovered embryos from the control group (group 1) of monkeys were blastocysts, while one out of six $(17 \%)$ embryos was degenerated. However, these differences were not statistically significant.

\section{Ultrastructural characteristics of monkey preimplantation stage embryos}

Among six embryos recovered from group 1 (vehicle only) control treatment animals, one transitional stage embryo and four zonal blastocysts were analyzed for transmission electron microscopic study, while seven preimplantation stage embryos were recovered from monkeys subjected to early luteal phase mifepristone treatment, of which four morulae and one zonal blastocyst were further processed for ultrastructural examination. Figure 1 shows some cardinal ultrastructural features in these embryos obtained from control and mifepristone-treated groups of animals.

As shown in Fig. 1A, the blastomeres in transitional stage embryos from control animals had large nuclei with generally dispersed heterochromatin and round to ovoid shaped mitochondria with dense matrices and without any clear cristae, they were present in clusters along with lipid droplets, while focal areas of cytoplasm lacked any organelles. Distinct inter-blastomere spaces were infrequently present and contained cellular debris. Zonal blastocysts recovered from control animals (group 1) had an enlarged cavity, which was often irregular in shape. Trophoblast cells in embryos collected from control animals exhibited marked polarity with numerous microvilli on an apical surface (Fig. 1B-E). Embryonal trophoblast cells overlying inner cell mass (ICM) cells were flattened and squamous in shape, while underlying cells of ICM showed numerous polyribosomes and coated caveolae and cytoplasmic vesicles were seen on free surfaces of blastomeres (Fig. 1B and C). Mitochondria were either elongated or large ovoid-shaped with discernible lamellar cristae with adjoining short strands of rough endoplasmic reticulum (Fig. 1C-F). Nuclei of ICM blastomeres were large with dispersed heterochromatin, intra-nuclear annulate lamellae, and prominent nuclear pores (Fig. 1B). Trophoblast cells showed long bundles of cytoplasmic filaments, distinctive apical junctions, infoldings of lateral cell membranes and desmosomes, rough endoplasmic reticulum (RER), occasional cisternae of RER filled with amorphous material, numerous plasma membrane-associated coated caveolae, cytoplasmic vesicles, and numerous microvilli on apical cell surfaces (Fig. 1E and F).

Morulae recovered from mifepristone-treated animals during the early luteal phase showed large intercellular spaces; a minimum degree of apposition of lateral cell membranes of blastomeres which, however, had retained their rounded cell shape with few apical microvilli; poorly developed junctional complexes and relatively small, pleiomorphic mitochondria, which were present in clusters (Fig. 1G). As shown in Figs $1 \mathrm{H}$ and I, blastomeres of the single blastocyst retrieved following mifepristone exposure lacked the typical features generally found in such differentiated cells. For example, junctional complexes, though present, were not as well developed or as extensive as observed in blastocysts collected from control animals; mitochondria remained undifferentiated, large, and often showed a high degree of vacuolation, endoplasmic reticulum were poorly developed (Fig. 1I). Furthermore, conspicuous absence of intra-cytoplasmic filaments was a marked feature of trophoblast cells in the single blastocyst obtained from mifepristone-exposed animals. Additionally, few morphological features, generally not seen in blastocysts from control animals, were found in blastomeres of the blastocyst recovered from mifepristonetreated monkeys. These included binucleate cells, large inter-blastomere spaces suggestive of lack of compaction, intra-cytoplasmic vacuoles, autolysosomes, lipofuscin, erythrophagolysosomes, myelinoid and multivesicular bodies. Large intra-cytoplasmic vacuoles containing cellular debris, as well as various cytoplasmic contents, lysosomes, multivesicular bodies, myelinoid bodies and fatty inclusion were also frequently seen in these blastomeres (Fig. 1J and $\mathrm{K}$ ).

\section{TNFa synthesis and secretion by monkey endometrial samples}

There was a significant $(P<0.01)$ increase in the per cent area occupied by immunoprecipitation of TNF $\alpha$ in glandular (group 1, $7.4 \pm 1.0 ;$ group 2, $50.3 \pm 6.0$ ) and vascular (group 1, $11.3 \pm 2.2$; group 2, $44.8 \pm 4.3$ ) compartments but not in stroma (group 1, $11.5 \pm 0.6$; group $2,14.6 \pm 1.1$ ) on day 6 following mifepristone treatment compared with control group samples in histometric analysis of per cent area of immunoprecipitation (Fig. 2).

Analysis of optical density data from dot blot and western blot experiments also revealed that the level of TNF $\alpha$ in homogenate $(0.67 \pm 0.07)$ and spent media $(1.62 \pm 0.03)$ was higher $(P<0.01)$ for endometrial samples collected from mifepristone-treated animals compared with that in homogenate $(0.28 \pm 0.04)$ and spent medium $(0.46 \pm 0.03)$ obtained from control animals. As shown in Fig. 3, western blot analysis revealed two bands (17 and $35 \mathrm{kD}$ ) in spent media from both groups. Since both bands are absent in antibody-preincubated negative control samples, we presume that the two bands in endometrial secretion arose from monomeric and dimeric TNF $\alpha$ presentation. Although we did not further investigate this issue, similar observation has been reported earlier (Ameloot et al. 2001).

The uterine fluid concentration of TNF $\alpha$ was significantly $(P<0.01)$ higher in mifepristone-treated animals $(4.4 \pm 0.5 \mathrm{ng} / 100 \mu \mathrm{g}$ protein) compared with control animals (1.2 $\pm 0.3 \mathrm{ng} / 100 \mu \mathrm{g}$ protein). 


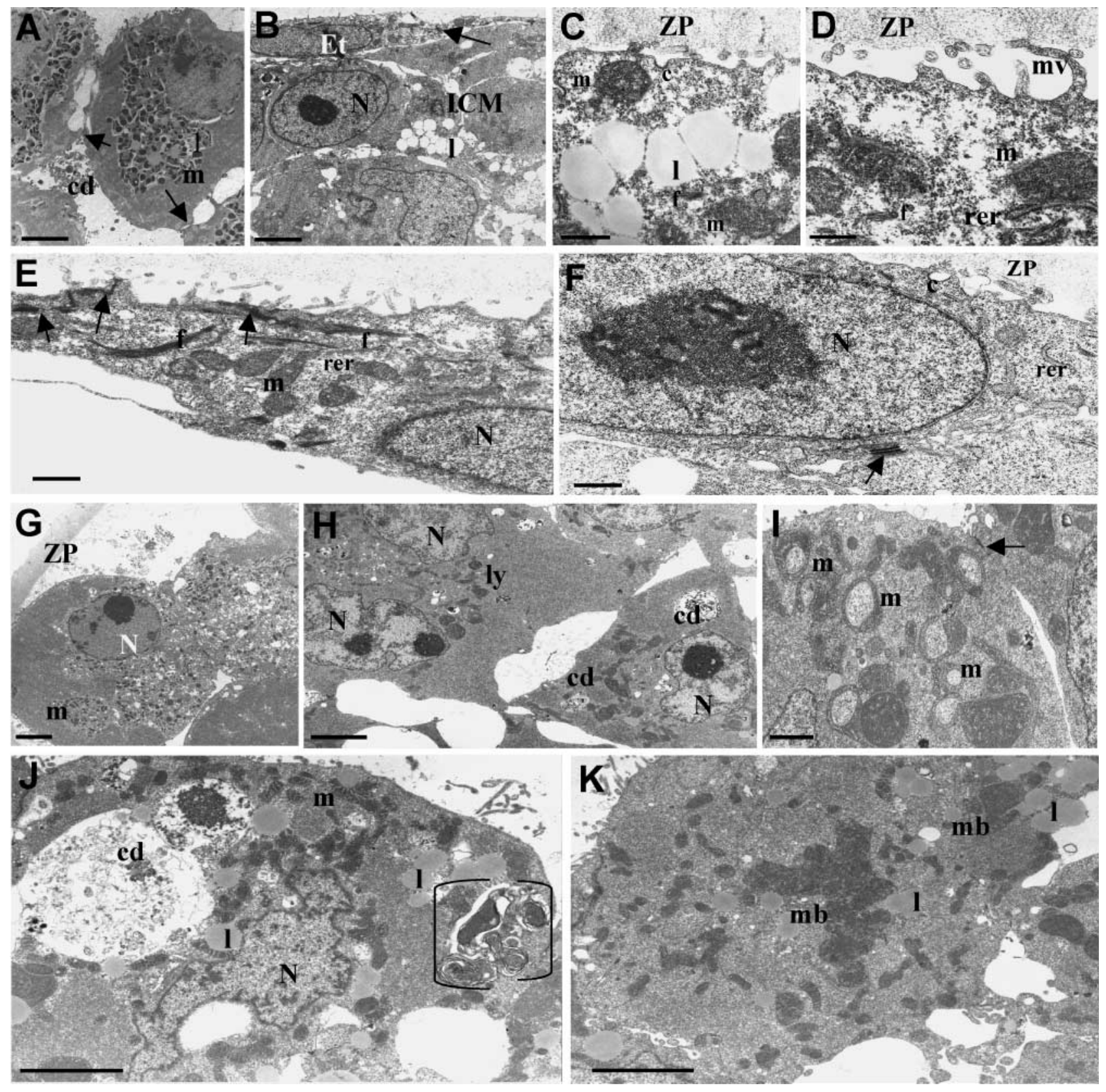

Figure 1 Ultrastructural characteristics of blastomeres of embryos from control (group 1) monkeys (A-F) and from mifepristone-treated (group 2) monkeys (G-K). Arrow, junctional complex; Brackets, myelinoid bodies; c, caveolae; cd, cellular debris; Et, embryonal trophoblast; $\mathrm{f}$, filaments; ICM, inner cell mass; I, lipid droplet; ly, lysosome; m, mitochondria; mb, multivesicular body; mv, microvilli; $\mathrm{N}$, nucleus; rer, rough endoplasmic reticulum; ZP, zona pellucida. Bars: $2 \mu \mathrm{m}(\mathrm{C}, \mathrm{D}) ; 3 \mu \mathrm{m}(\mathrm{F}, \mathrm{H}-\mathrm{K}) ; 5 \mu \mathrm{m}(\mathrm{E}) ; 6 \mu \mathrm{m}(\mathrm{G}) ; 10 \mu \mathrm{m}(\mathrm{A}, \mathrm{B})$.

\section{TNF-RI in the preimplantation stage monkey embryo}

As shown in Fig. 4, TNF-RI was localized in both inner cell mass and polar trophoblast cells in monkey blastocysts.

\section{Developmental status of mouse preimplantation stage embryos following TNFa exposure in vitro}

Tables 2 and 3 show the details of developmental characteristics of morulae and blastocysts collected on day 4 of gestation and cultured for $24 \mathrm{~h}$ in vitro in the presence of different concentrations of TNF $\alpha$.

As shown in Table 2, at morula stage TNF $\alpha$, at a concentration of $0.5 \mathrm{ng} / \mathrm{ml}$ (Group lb), resulted in a marginally higher $(P<0.05)$ incidence of degeneration, while there was no significant change in the per cent morulae developed into blastocysts compared with controls (Group la). The number of embryos showing degenerated and arrested features, however, increased following exposure to higher concentrations (5 and $50 \mathrm{ng} / \mathrm{ml}$ ) of $\mathrm{TNF} \alpha$, as compared 

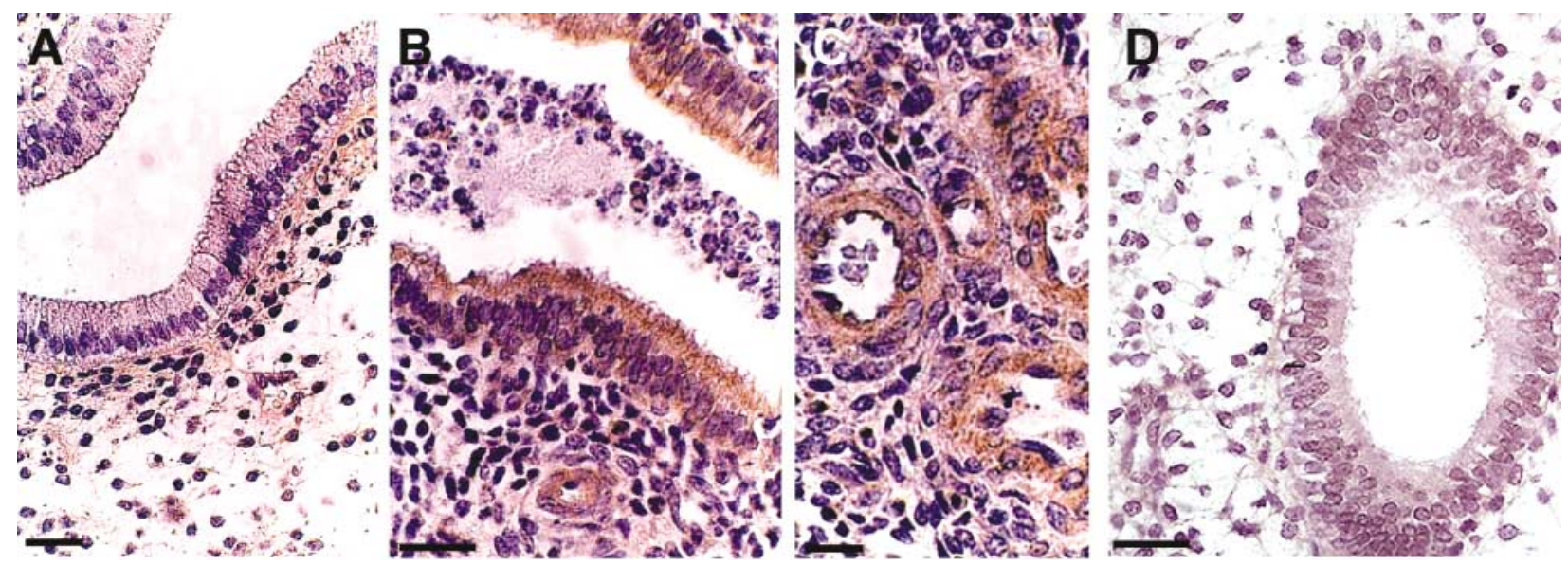

Figure 2 Immunohistochemical localization of TNF $\alpha$ antigen in endometrial tissue collected on day 6 after ovulation from control (group 1) monkeys (A) and from mifepristone-treated (Group 2) monkeys (B-D). Compared with the control sample, mifepristone treatment resulted in a high degree of immunostaining for TNF $\alpha$ in the apical zone of glandular epithelial cells (B) and in the vascular compartment (C). No immunostaining was found when the primary antibody was immunoadsorbed with TNF $\alpha$ antigen (D) as described in the Materials and Methods section. Bars: $10 \mu \mathrm{m}(\mathrm{C}) ; 20 \mu \mathrm{m}(\mathrm{A}, \mathrm{B}, \mathrm{D})$.

with group la (control) and group lb (TNF- $\alpha, 0.5 \mathrm{ng} / \mathrm{ml})$. As a result, the per cent of morulae undergoing blastocyst development in group Ic $(\mathrm{TNF}-\alpha, 5 \mathrm{ng} / \mathrm{ml})$ and group Id (TNF $\alpha, 50 \mathrm{ng} / \mathrm{ml})$ was significantly $(P<0.001)$ less than that found in group la (control) and group $\mathrm{lb}$ (TNF $\alpha$, $0.5 \mathrm{ng} / \mathrm{ml}$ ).

As shown in Table 3, when blastocysts were incubated with different doses of TNF $\alpha$, a dose dependent increase $(P<0.01$ for group $\mathrm{Ilb}$, and $P<0.001$ for groups Ilc and IId) in the per cent of embryos showing obvious degeneration, and a dose dependent decrease $(P<0.05$ for group $\mathrm{IIb}$, and $P<0.001$ for groups IIc and IId) in the development of embryos to form expanded blastocysts as compared with those in control group embryos (group lla) were recorded. No statistically significant change was observed in the per cent of blastocysts degenerated or expanded between group IIb $(\mathrm{TNF} \alpha, 0.5 \mathrm{ng} / \mathrm{ml})$ and group Ilc $(\mathrm{TNF} \alpha, 5 \mathrm{ng} / \mathrm{ml})$. Also, no change was observed in the per cent blastocysts expanded between group IIc (TNF $\alpha$, $5 \mathrm{ng} / \mathrm{ml}$ ) and group Ild $(\mathrm{TNF} \alpha, 50 \mathrm{ng} / \mathrm{ml})$. However, the per cent of blastocysts degenerated was higher in group IId as compared with group IIb $(P<0.01)$ and group Ilc $(P<0.05)$. On the other hand, there was no change in the per cent number of blastocysts hatched following exposure to $0,0.5$, and $5.0 \mathrm{ng} / \mathrm{ml} \mathrm{TNF} \alpha$ in culture medium; however it decreased significantly $(P<0.01)$ with exposure to very high concentrations of TNF $\alpha(50 \mathrm{ng} / \mathrm{ml})$ as compared with all other treatment groups.

\section{Ultrastructural characteristics of mouse preimplantation stage embryos following TNFa exposure in vitro}

Morulae and blastocysts collected on day 4 from mated female mice, without apparent abnormality as seen under stereozoom microscope were subjected to in vitro culture in medium containing different doses of $\mathrm{TNF} \alpha(0,0.5,5$ and $50 \mathrm{ng} / \mathrm{ml}$ ) for $24 \mathrm{~h}$ following which apparently normal looking blastocysts were fixed for transmission electron microscope (TEM) examination. Figure 5 highlights the ultrastructural features of blastocysts developed from morulae and blastocysts, respectively, after $24 \mathrm{~h}$ culture with or without TNF $\alpha$. TEM examination revealed that morulae that did develop into blastocysts in vitro, however, showed a higher degree of degenerative features in blastomeres following exposure to $T N F \alpha$, especially at higher concentrations $(5 \mathrm{ng} / \mathrm{ml}$ and $50 \mathrm{ng} / \mathrm{ml}$ ) studied (Fig. $5 \mathrm{C}$ and D) compared with control embryos (Fig. 5A and B).

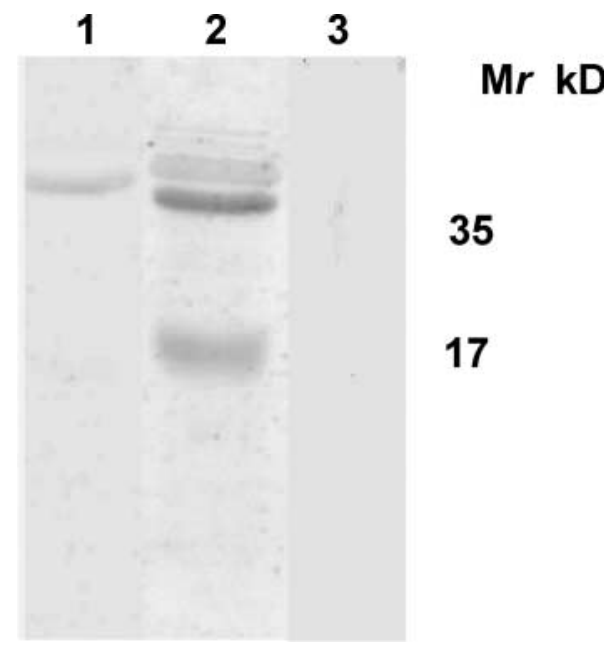

Figure 3 Western immunoblot for TNF $\alpha$ in spent medium of endometrial tissue collected on day 6 after ovulation from control (lane 1) and mifepristone-treated (lane 2) monkeys. Lane 3 shows spent medium of sample used in lane 2 that had been preincubated with neutralizing antibody as described in the Materials and Methods section. Optical density of both bands ( $\mathrm{Mr} 35$ and $17 \mathrm{kD}$ ) was considered for densitometric analysis. 

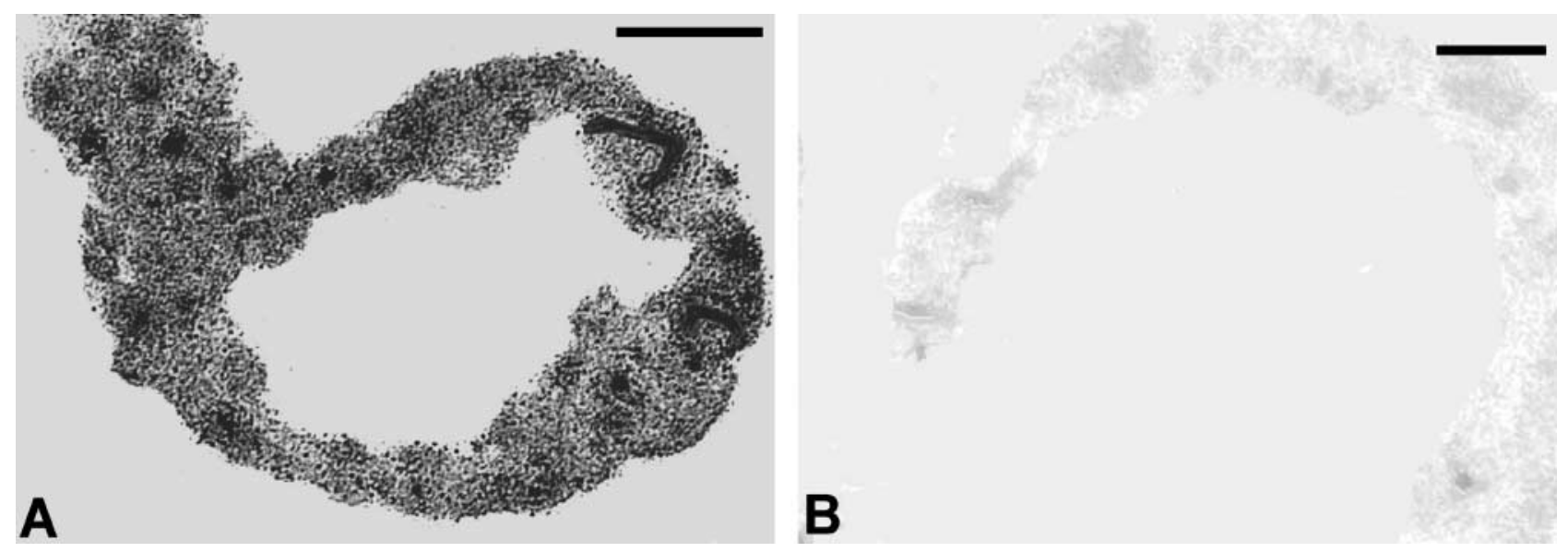

Figure 4 Rhesus monkey blastocyst ( $1 \mu \mathrm{m}$ section) showing immunolocalization for TNF-RI (A). A contiguous $1 \mu \mathrm{m}$ embryo section showed no staining for TNF-RI following incubation in medium lacking the primary antibody (B). Bar: $25 \mu \mathrm{m}$.

All blastocysts in this group (control and TNF $\alpha$-exposed) were in either substage one or two of their development with clear blastocoelic cavities according to the classification described earlier (Nadijcka \& Hillman 1974). Ultrastructural examination of blastocysts from the control group revealed close clustering of mitochondria which were beginning to show cristae, but matrix remained mostly electron-dense; mitochondria were found closely associated with short strands of RER and small to large cisternae of RER were often engorged with amorphous inclusions; lipid droplets were occasionally lined with discrete glycogen particles. A large nucleus bearing 'honey-

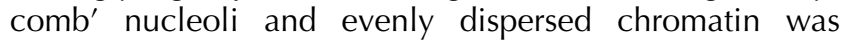
characteristically observed. Distinctive apical and basolateral junctional complexes were discernible in such control group blastocysts (Fig. 5A and B). Following exposure to $\mathrm{TNF} \alpha$, morulae developed into blastocysts but several degenerative features were clearly distinguishable: embryonic trophoblast showed loss of polarized features with apical as well as basolaterally distributed microvilli in cells; these cells were largely cuboidal and irregular in shape and showed a high degree of fatty inclusions, reactive lysosomes, lipofuscin, degenerative vacuoles, intracytoplasmic villi, blastomeres showing large intercellular spaces, woolly transformation of mitochondria and marked distortion in nuclear membrane contour more predominantly in blastomeres of the inner cell mass (Fig. 5C and $\mathrm{D}$ ). These features were commonly not seen in the control group blastocysts.

Blastocysts incubated for $24 \mathrm{~h}$ in control medium underwent development to substage three type differentiation with ICM showing epiblast and proximal entoderm layer (Fig. 5E and F). Mitochondrial differentiation was found to be distinctive at this stage of development; polarization of cytoplasmic organelles characterized by distribution of mitochondria and Golgi zones in peri-nuclear location was seen (Fig. 5E and F). Blastocysts exposed to TNF $\alpha$ at varying doses showed various degrees of cellular degenerative features (Fig. 5G-J) which included large intra-cytoplasmic vacuoles enclosing cellular debris, lipid droplets, lipofuscin containing large residual bodies, large conglomerations of glycogen, primitive types of myelinoid structures reminiscent of such bodies found in monkey blastocysts recovered from mifepristone-exposed animals (Fig. 1J and K), loss of mitochondrial differentiation and numerous primitive junctional complexes unlike blastocysts from the control group. Although stereological analysis was not done in the present study, the relative abundance of such degenerative features on subjective analysis was considered fewer in blastomeres of blastocysts exposed to TNF $\alpha$ compared with that found in morulae exposed to TNF $\alpha$.

\section{Protein synthesis in mouse preimplantation stage embryos following TNFa exposure in vitro}

Table 4 shows the data of ${ }^{35}$ S-methionine labeled proteins in spent media as well as in lysates of morulae (group I) and blastocysts (group II) with and without TNF $\alpha$ (0.5, 5.0 , and $50.0 \mathrm{ng} / \mathrm{ml}$ ) treatment in vitro. It is evident from the data that embryonic protein synthesis as well as protein secretion were higher $(P<0.05)$ at blastocyst stage compared with morula stage between respective sets of different treatments (for example between control-treated morulae and blastocysts, $0.5 \mathrm{ng} \mathrm{TNF} \alpha / \mathrm{ml}$ treated morula and blastocysts, $5.0 \mathrm{ng} \mathrm{TNF} \alpha / \mathrm{ml}$ treated morula and blastocysts, and $50 \mathrm{ng} \mathrm{TNF} \alpha / \mathrm{ml}$-treated morula and blstocysts) and that exposure to 5.0 and $50.0 \mathrm{ng} \mathrm{TNF} \alpha$ per ml medium resulted in statistically significant $(P<0.05)$ inhibition of embryonic protein synthesis both at morula and blastocyst stages, while protein secretion by morula stage and blastocyst stage embryos was significantly $(P<0.01)$ affected even at $0.5 \mathrm{ng} \mathrm{TNF} \alpha$ per $\mathrm{ml}$ medium.

\section{Discussion}

The results of the present study confirm that subcutaneous administration of mifepristone at a dose of $2 \mathrm{mg}$ per $\mathrm{kg}$ 

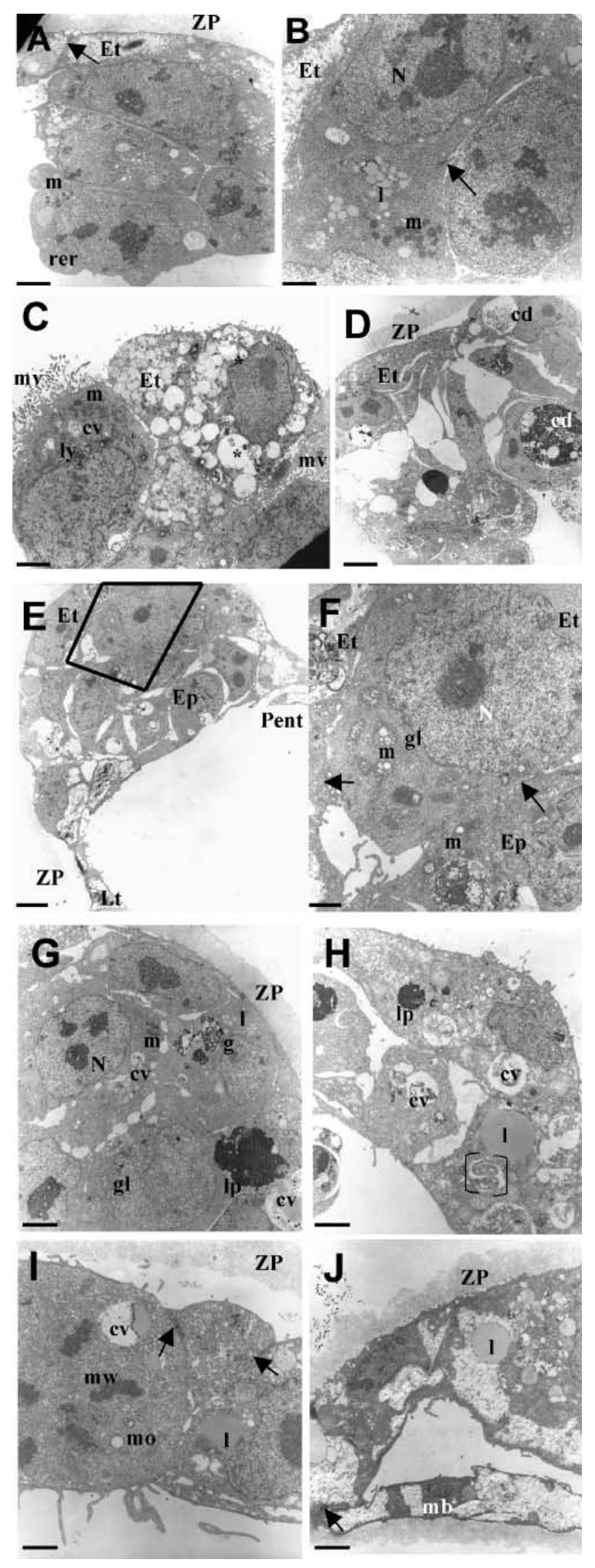

body weight adversely affects the growth of preimplantation stage embryos, particularly from morula stage onwards (Ghosh et al. 1997, 2000) and that mouse preimplantation stage embryos exposed to TNF $\alpha$ in vitro exhibited failure of morula-to-blastocyst transition in a dose-dependent manner. Furthermore, ultrastructural examination revealed that mouse embryos exposed in vitro to TNF $\alpha$ showed many similarities in their ultrastructural features to blastomeres of embryos exposed in vivo to mifepristone with loss of trophoblast cell polarity, lack of mitochondrial maturity and a higher abundance of degenerative features. The degenerative features like the high degree of fatty inclusion, lipofuscin, myelin bodies and inter-blastomere spaces as observed in the blastomeres of embryos retrieved from mifepristone-exposed monkeys and in the blastomeres of mouse embryos exposed in vitro to TNF $\alpha$ are reminiscent of the reported ultrastructural characteristics of blastomeres of $t^{12} / t^{12}$ and $t w^{32} / t w^{32}$ mouse embryos (Hillman et al. 1970, Hillman \& Hillman 1975). Interestingly, both $t^{12} / t^{12}$ and $t w^{32} / t w^{32}$ embryos show delay in the process of morula-to-blastocyst transition (Hillman et al. 1970, Hillman \& Hillman 1975), and lose their viability at very early stages of gestation (Nadijcka \& Hillman 1975). We have earlier reported that monkey embryos exposed in vivo to mifepristone fail to yield evolutive implantation (Ghosh et al. 1997). Psychoyos \& Prapas (1987) observed that administration of mifepristone to rats on days 1 and 2 of pregnancy resulted in a blockade of the morula-to-blastocyst transition.

The possibility that TNF $\alpha$ could be an effector candidate in mediating the embryotoxic effect of mifepristone is further substantiated by the fact that: (i) endometrial synthesis and secretion of TNF $\alpha$ is increased resulting in its higher concentration in luminal milieu following early luteal phase mifepristone treatment, and (ii) preimplantation blastocyst stage monkey embryos exhibit the receptor for TNF $\alpha$ (TNF-RI).

Although it is possible that mifepristone may directly act on preimplantation stage embryos, indirect evidence that: (i) mifepristone does not affect the growth of preimplantation stage embryos of the rhesus monkey (Wolf et al. 1990), and (ii) there was no detectable mifepristone in the

Figure 5 Ultrastructural characteristics of mouse blastocysts developed in vitro following $24 \mathrm{~h}$ culture of morulae in control medium (A, B) and in medium containing $0.5 \mathrm{ng} / \mathrm{ml}$ (C) and $50 \mathrm{ng} / \mathrm{ml}$ (D) TNF $\alpha$. Ultrastructural features of mouse blastocysts grown for $24 \mathrm{~h}$ in control medium (E, F) and in medium containing $0.5 \mathrm{ng} / \mathrm{ml}(\mathrm{G}), 5.0 \mathrm{ng} / \mathrm{ml}(\mathrm{H}, \mathrm{I})$ and $50 \mathrm{ng} / \mathrm{ml}(\mathrm{J}) \mathrm{TNF} \alpha$. Arrow, junctional complex; asterix, intracytoplasmic vacuole; brackets, myelinoid bodies; cd, cellular debris; $\mathrm{Cv}$, intracytoplasmic vacuole; Ep, central epiblast; Et, embryonal trophoblast; g, glycogen; gl, perinuclear Golgi zone; I, lipid droplet; Ip, lipofuscin; Lt, elongated lateral trophoblast; ly, lysosome; m, mitochondria; mb, multivesicular body; mo, vacuolated mitochondria; mw, woolly mitochondria; mv, microvilli; N, nucleus; Pent, proximal entoderm; rer, rough endoplasmic reticulum; ZP, zona pellucida. Note that the inset area in (E) is shown in enlarged form in (F). Bars: $2 \mu \mathrm{m}$ (F); $3 \mu \mathrm{m}(\mathrm{B}, \mathrm{I}, \mathrm{J}) ; 4 \mu \mathrm{m}(\mathrm{C}) ; 6 \mu \mathrm{m}(\mathrm{G}, \mathrm{H}) ; 10 \mu \mathrm{m}(\mathrm{A}, \mathrm{E}) ; 15 \mu \mathrm{m}(\mathrm{D})$. 
luminal fluid following luteal phase administration of mifepristone $(2 \mathrm{mg} / \mathrm{kg}$ body weight) to rhesus monkeys (unpublished data), casts serious doubt on this possibility. We have demonstrated earlier that low dose mifepristone applied during the early luteal phase does not affect the serum concentrations of estradiol-17 $\beta$ and progesterone and thereby ovarian functions in the rhesus monkey (Ghosh \& Sengupta 1993). It now appears likely that early luteal phase antiprogestin action affects endometrial function in a way that the luminal environment becomes hostile and cannot support preimplantation embryo growth (Antonakis et al. 1994, Beir-Hellwig et al. 1994, Ding et al. 1994, Psychoyos et al. 1995, Qui et al. 2001). This notion is indeed substantiated by the observation that passive immunization against progesterone in the mother during early pregnancy resulted in arrested embryonic growth in mice, rats and ferrets (Wang et al. 1984, Rider \& Heap 1986, Phillips et al. 1988).

Mifepristone is a potent anti-glucocorticoid and antiprogesterone (Philibert, 1984). Generally, mifepristonemediated inhibition of glucocorticoid activity in mammalian tissues, as well as inhibition of progesterone action specifically in endometrial cells, tend to increase TNF $\alpha$ (Gaillard et al. 1985, Busso et al. 1987, Lazar et al. 1992, Tabibzadeh et al. 1995). In an interesting study, Laird et al. (1996) have demonstrated that there was a down regulation of TNF $\alpha$ production by secretory phase endometrium in the presence of progesterone in vitro. Therefore, we anticipated that early luteal phase application of mifepristone blocks progesterone and glucocorticoid action in the implantation stage endometrium and upregulates endometrial synthesis and secretion of TNF $\alpha$. The results of the present study have now indeed demonstrated that mifepristone administration on day 2 after ovulation results in increased endometrial synthesis and secretion of TNF $\alpha$ on day 6 after ovulation.

In the next phase, we tested the hypothesis that a high level of luminal TNF $\alpha$ affects embryo growth. Because of practical and ethical constraints this hypothesis could not be tested using monkey embryos, and therefore it was tested using mouse embryos. TNF $\alpha$ affects morula-toblastocyst transition and blastocyst growth in vitro in a dose-dependent manner. Morphological changes, based on ultrastructural examination, and functional changes, based on the profile of proteins synthesized and released by apparently normal-looking embryos exposed to TNF $\alpha$ in vitro, were significantly different compared with those found in embryos in control treatment. The possibility that $\mathrm{TNF} \alpha$ present in culture medium can adversely affect the growth of the preimplantation stage embryo is also substantiated by several reports based on studies using different models. TNF $\alpha$ has been shown in vivo and in vitro to reduce the viability of mouse blastocysts, and rat blastocysts along with high levels of apoptotic cell death (Pampfer et al. 1994a,b, Wuu et al. 1999, Kurzawa et al. 2001). The observation in the present study that preimplantation stage embryos express receptors for $\mathrm{TNF} \alpha$ corroborates well with earlier studies on mouse preimplantation stage embryos (Pampfer et al. 1994b, 1995).

Morula-to-blastocyst transition is a critical step in the process of embryogenesis characterized by ultrastructural polarization (Enders et al. 1990, Ducibella et al. 1995, Ohsugi et al. 1999) and specific profiles of proteins synthesized at this developmental stage (Zheng et al. 1993, Shi et al. 1994, Sasaki et al. 1999). Mouse blastocysts allowed to develop in vivo are classified into four substages based on their ultrastructural features: substage one, when blastoceolic cavity is well formed but not expanded, substage two, when the cavity is expanded but ICM cells do not show any clear-cut differentiation, substage three, when ICM shows differentiation into epiblast and proximal entoderm, and substage four, when visceral entoderm develops and forms a continuous layer around the blastocyst cavity (Nadijcka \& Hillman 1974). Embryos in the control group showed development until substage three, which was not achieved by embryos exposed to $\mathrm{TNF} \alpha$. It is interesting to note that in the present study, though a population of morulae underwent differentiation into blastocysts, their development was significantly compromised after TNF $\alpha$ exposure in vitro, characterized by a loss of cell polarity in trophoblast cells, lack of mitochondrial maturity, and a higher occurrence of inter-blastomere space, intra-cytoplasmic vacuoles, lysosomes and lipofuscin and multivesicular bodies (Ghadially 1988). It appears that input from the immediate microenvironment can influence these processes (Neider et al. 1987, Enders et al. 1989). A subgroup of embryos both in mice and monkeys had escaped the adverse effects putatively mediated by TNF $\alpha$. In the present study, one out of seven embryos could attain blastocyst stage, and in our previous reports one out of twelve embryos, and five out of sixteen embryos could attain blastocyst stage despite application of mifepristone to rhesus monkeys (Ghosh et al. 1997, 2000). In mice, more than $20 \%$ of morulae could develop into blastocysts and a similar percentage of blastocysts could expand and hatch even in the presence of TNF $\alpha$, despite a dose-dependent increase in the number of degenerated embryos. It has been shown in mouse that the morphological event of cavitation at the morula stage can occur even when either DNA replication was inhibited (Dean \& Rossant 1984) or cytokinesis was blocked (Pratt et al. 1981). It is also possible that these embryos do not express the functional receptors for TNF $\alpha$ or the proteins required for their down-stream signal transduction (Takahashi et al. 1995, Sridhar et al. 2001). The significance of this observation is only speculative at this point in time. It may be conjectured that the group of embryos, which are relatively resistant to $\mathrm{TNF} \alpha$, may escape environmental hostility and thereby give an advantage of providing effort toward establishing pregnancy despite the possibility that such environmental hostility may cause some defect in the organism. Alternatively, based on 
experiments using TNF $\alpha$ positive and TNF $\alpha$ knock-out mice, Toder et al. (2003) concluded that TNF $\alpha$ boosts death signaling to kill the embryo if initial damages triggered by detrimental stimuli culminate in structural anomalies and stimulate protective mechanisms if the repair of these damages may prevent maldevelopment.

It is to be noted that morulae which could develop in mifepristone-treated female monkeys, and in the presence of TNF $\alpha$ in mouse embryo cultures, exhibited a higher abundance of ultrastructural defects in their blastomeres along with a deficit in protein synthesis. Despite the fact that some events in embryogenesis may proceed in a fixed action pattern even in a hostile environment, environmental deficit or hostility can leave an unfavourable imprint, which in turn may adversely affect the required sufficiency and time synchrony of interactions between the embryo and endometrium resulting in failure of blastocyst implantation. This notion is supported by the observation that apparently normal-looking preimplantation stage embryos retrieved from luteal phase mifepristone-treated monkeys could not support implantation and evolutive pregnancy (Ghosh et al. 1997), and that apparently normal-looking mouse blastocysts exposed to TNF $\alpha$ in vitro failed to implant (Wuu et al. 1999).

Thus, we conclude that delay in embryo development along with the onset of degenerative changes observed in monkey preimplantation stage embryos following mifepristone exposure may be contributed by increased TNF $\alpha$ concentrations in uterine luminal fluid. The possibility that early luteal phase mifperistone administration can affect the equilibrium of a larger network of cytokines in the endometrium, involving transforming growth factor $\beta$ (TGF $\beta$ ), interferon $\gamma$ (IFN $\gamma$ ) and interleukins (ILs), besides TNF $\alpha$ (Antanakis et al. 1994, Rotello et al. 1991, Shaarawy \& Nagui 1997) resulting in irreversible damage to the preimplantation embryo needs to be examined. Additionally, the relative depletion of specific growth factors like epidermal growth factor (EGF) and insulin like growth factors (IGFs) in the endometrium may also potentiate detrimental effect of TNF $\alpha$ (Wu et al. 1996, Ho et al. 1999) on embryo growth following luteal phase administration of mifepristone.

\section{Acknowledgement}

This research was funded by the World Health Organization - The Rockefeller Foundation Initiative on Implantation Research.

\section{References}

Ameloot P, Declerg W, Fiers W, Vandenabeele P \& Brouckaert $\mathbf{P}$ 2001 Heterotrimers formed by tumor necrosis factor of different species or mutiens. Journal of Biological Chemistry $\mathbf{2 7 6}$ 27098-27103.

Antonakis N, Geaorgoulias V \& Margioris AN 1994 Invitro differential effects of the antiglucocorticoid RU486 on the release of lymphokines from mitogen activated nomal human lymphocytes. Journal of Steroid Biochemistry and Molecular Biology $51 \quad 67-72$.

Beier-Hellwig M, Hegele-Hartung C, Mootz U \& Beier-Hellwig K 1994 Modification of endometrial cell biology using progesterone antagonists to manipulate the implantation widow. Human Reproduction 9 98-115.

Ben-Yair E, Less A, Lev S, Ben-yeshoshua L \& Tartakovsky B 1997 Tumor necrosis factor alpha binding to human and mouse trophoblast. Cytokine 9 830-836.

Busso N, Collart M, Vassalli JD \& Belin D 1987 Antagonist effect of RU 486 on transcription of glucocorticoid-regulated genes. Experimental Cell Research 173 425-430.

Dean WL \& Rossant J 1984 Effect of delaying DNA replication on blastocysts formation in the mouse. Differentiation 26 134-137.

Ding YQ, Zhu LJ, Bagchi MK \& Bagchi IC 1994 Progesterone stimulates calcitonin gene expression in the uterus during implantation. Endocrinology 135 2265-2274.

Ducibella T, Albertini DF, Anderson E \& Biggers JD 1995 The preimplantation mammalian embryo: characterization of intercellular junctions and their appearance during development. Developmental Biology 45 231-250.

Edwards RG 1995 Physiological and molecular aspects of human implantation. Human Reproduction 10 1-13.

Enders AC, Boatman D, Morgan P \& Bavister BD 1989 Differentiation of blastocysts derived from in vitro-fertilized rhesus monkey ova. Biology of Reproduction 41 715-727.

Enders AC, Lantz KC \& Schlafke S 1990 The morula-blastocyst transistion in two old world primates: the baboon and rhesus monkey. Journal of Medicine and Primatology 19 725-747.

Gaillard RC, Poffet D, Riondel AM \& Saurat JH 1985 RU 486 inhibits peripheral effects of glucocorticoids in humans. Journal of Clinical Endocrinology and Metabolism 61 1009-1011.

Ghadially FN 1988 Ultrastructural Pathology of the Cell and Matrix, edn 3, vol 1 \& 2. London: Butterworths.

Ghosh D \& Sengupta J 1993 Anti-nidatory effect of a single, postovulatory administration of mifepristone (RU 486) in the rhesus monkey. Human Reproduction 8 552-558.

Ghosh D \& Sengupta J 1998 Recent development in endocrinology and paracrinology of blastoocyst implantation in the primate. Human Reproduction Update 4 153-168.

Ghosh D, Kumar PGL \& Sengupta J 1997 Early luteal phase administration of mifepristone inhibits preimplantation embryo development and viability in the rhesus monkey. Human Reproduction 12 575-582.

Ghosh D, Kumar PGL \& Sengupta J 1998 Effect of early luteal phase administration of mifepristone (RU486) on leukaemia inhibitory factor, transforming growth factor beta and vascular endothelial growth factor in the implantation stage endometrium of the rhesus monkey. Journal of Endocrinology 157 $115-125$.

Ghosh D, Lalitkumar PGL, Wong VJ, Hendrickx AG \& Sengupta J 2000 Preimplantation embryo morphology following early luteal phase anti-nidatory treatment with mifepristone (RU486) in the rhesus monkey. Human Reproduction 15 180-188.

Ghosh D, Sengupta J \& Hendrickx AG 1996 Effect of a single dose, early luteal phase administration of mifepristone (RU 486) on implantation stage endometrium in the rhesus monkey. Human Reproduction 11 2026-2035.

Gogstad GO \& Krutnes MB 1982 Measurement of protein in cell suspensions using the coomassie blue dye-binding assay. Annals of Biochemistry 126 355-359.

Hill JA, Haimovici F \& Anderson DJ 1987 Products of activated lymphocytes and macrophages inhibit mouse embryo development in vitro. Journal of Immunology 139 2250-2254.

Hillman N \& Hillman R 1975 Ultrastructural studies of $t^{\mathrm{w} 32} / t^{\mathrm{w} 32}$ mouse embryos. Journal of Embryology and Experimental Morphology 33 685-696. 
Hillman N, Hillman R \& Wileman G 1970 Ultrastructural studies of cleavage stage $t^{12} / t^{12}$ mouse embryos. American Journal of Anatomy $128311-340$.

Ho S, Winkler-Lowen B, Morrish DW, Dakour J, Li H \& Guilbert LJ 1999 The role of Bcl-2 expression in EGF inhibition of TNFalpha/IFN-gamma-induced villous trohoblast apoptosis. Placenta 20 423-430.

Hogan B, Beddington R, Costantini F \& Lacy E 1994 Recovery, culture and transfer of embryos and germ cells. In Manipulating the Mouse Embryo: A Laboratory Manual, 2nd edn, SectC pp 125-188. New York: Cold Spring Harbor Laboratory.

Kurzawa R, Glabowski W \& Wenda-Rozewicka L 2001 Evaluation of mouse preimplantation embryos cultured in media enriched with insulin-like growth factor I and II, epidermal growth factor and tumor necrosis factor alpha. Folia Histochemisrty and Cytobiology $39245-251$.

Lachapelle MH, Miron P, Hemmings R, Falcone T, Granger L, Bourque J \& Langlais J 1993 Embryonic resistance to tumor necrosis factor-alpha mediated cytotoxicity: novel mechanism underlying maternal immunological tolerance to the fetal allograft. Human Reproduction 8 1032-1038.

Laird SM, Tuckerman EM, Saravelos H \& Li TC 1996 The production of tumor necrosis factor alpha (TNF-alpha) by human endometrial cells in culture. Human Reproduction 11 1318-1323.

Lazar G Jr, Duda E \& Lazar G 1992 Effect of RU 38486 on TNF production and toxicity. FEBS Letter 308 137-140.

Nadijcka M \& Hillman N 1974 Ultrastructural studies of the mouse blastocyst substages. Journal Embryology and Experimental Morphology 32 675-695.

Nadijcka M \& Hillman $\mathbf{N} 1975$ Studies of $t^{6} / t^{6}$ mouse embryos. Journal Embryology and Experimental Morphology 33 679-713.

Neider GN, Weitlauf HM \& Suda-Hartman M 1987 Synthesis and secretion of stage specific pre-implantation mouse embryos. Biology of Reproduction 36 687-699.

Ohsugi M, Butz S \& Kemler R 1999 Beta-catenin is a major tyrosinephosphorylated protein during mouse oocyte maturation and preimplantation development. Development and Dyn 216 $168-176$.

Pampfer S, Moulaert B, Vanderheyden I, Wuu YD \& De Hertogh $R$ 1994a Effect of tumor necrosis factor alpha on rat blastocysts growth and glucose metabolism. Journal of Reproduction and Fertility 10 199-206.

Pampfer S, Wuu YD, Vanderheyden I \& Hertogh RD 1994b Expression of tumor necrosis factor- $\alpha$ (TNF- $\alpha$ ) receptors and selective effect of TNF- $\alpha$ on the inner cell mass in mouse blastocysts. Endocrinology 134 206-212.

Pampfer S, Vanderheyden I, Vesela J \& De Hertog R 1995 Neutralization of tumor necrosis factor alpha (TNF alpha) action on cell proliferation in rat blastocysts by antisence oligodeoxyribonucleotides directed against TNF alpha p60 receptor. Biology of Reproduction 52 1316-1326.

Philibert D 1984 RU38486, an original multifaceted antihormone in vivo. In Adrenal Steroid Antagonism, pp 101-77. Ed. MK Agarwal. Berlin: Walter deGruyter and Co.

Phillips A, Hahn DW, McGuire J, Wang MW, Heap RB, Rider V \& Taussig MJ 1988 Inhibition of pregnancy before and after implantation in rats with monoclonal antibody against progesterone. Contraception 38 109-116.

Polan ML, Simon C \& Frances A 1995 Role of embryonic factors in human implantation. Human Reproduction $1022-29$.

Pratt HPM 1987 Isolation, culture and manuplatation of pre-implantation mouse. In Mammalian development - a practical approach, 1st Edn, Chap 2 pp 13-42. Ed. M Monk. Oxford: IRL Press Limited.

Pratt HM, Chakraborty J \& Surani MAH 1981 Molecular and morphological differentiation of mouse blastocysts after manipulations of compaction with cytochalain D. Cell 26 279-292.

Psychoyos A \& Prapas I 1987 Inhibition of egg development and implantation in rats after post-coital administration of the progresterone antagonist RU 486. Journal of Reproduction and Fertility 80 487-491.

Psychoyos A, Nikas G, Sarantis L \& Gravanis A 1995 Hormonal antiimplantation agents: antiprogestins. Human Reproduction $\mathbf{1 0}$ 140-150.

Qui X, Sun X, Christow A, Stabi B \& Gemzell-Danielsson K 2001 The effect of mifepristone on the expression of insulin-like growth factor binding protein-1, prolactin and progesterone receptor mRNA and protein during the implantation phase in human endometrium. Molecular Human Reproduction $\mathbf{8}$ 998-1004.

Rider V \& Heap RB 1986 Heterologous antiprogesterone monoclonal antibody arrests early embryonic development and implantation in the ferret (Mustela putorius). Journal of Reproduction and Fertility 76 459-470.

Rotello RJ, Leiberman RC, Purchio AF \& Gerschenson LE 1991 Coordinated regulaston of apoptosis and cell proliferation by transforming growth factor beta 1 in cultured uterine epithelial cells. PNAS $883412-3415$.

Sasaki R, Nakayama T \& Kato T 1999 Microelectrophoretic analysis of changes in protein expression patterns in mouse oocytes and preimplantation embryos. Biology of Reproduction $\mathbf{6 0}$ $1410-1418$.

Sengupta J \& Ghosh D 2000 Role of progesterone on peri-implantation stage endometrium-embryo interaction in the primate. Steroids $65753-762$.

Shaarawy M \& Nagui AR 1997 Enhanced expression of cytokines may play a fundamental role in the mechanism of immunologically mediated recurrent spontaneous abortion. Acta Obstetrics and Gynecology Scandinavia 76 205-211.

Shi CZ, Collins HW, Garside WT, Buettger CW, Matchinsky FM \& Heyner S 1994 Protein database for compacted eight-cell and blastocysts-stage mouse embryos. Molecular Reproduction and Development 37 34-47.

Sridhar S, Ali AA, Liang Y, El Etreby MF, Lewis RW \& Kumar MV 2001 Differential expression of members of the tumor necrosis factor related apoptosis-induced ligand pathway in prostate cancer cells. Cancer Research 61 7179-7183.

Tabibzadeh S \& Babaknia A 1995 The signals and molecular pathways involved in implantation, a symbiotic interaction between blastocyst and endometrium involving adhesion and tissue invasion. Human Reproduction 10 1579-1602.

Tabibzadeh S, Zupi E, Babaknia A, Liu R, Marconi D \& Romanini C 1995 Site and menstrual cycle-dependent expression of proteins of the tumor necrosis factor (TNF) receptor family, and BCL-2 oncoprotein and phase-specific production of TNF alpha in human endometrium. Human Reproduction 10 277-286.

Takahashi N, Brouckaert P \& Fiers W 1995 Mechanism of tolerance to tumor necrosis factor: receptor-specific pathway and selectivity. American Journal of Physiology 269 R398-405.

Toder V, Fein A, Carp H \& Torchinsky A 2003 TNF-alpha in pregnancy loss and embryo maldevelopment: a mediator of detrimental stimuli or a protector of the fetoplacental unit? Journal of Assisted Reproduction and Genetics 20 73-81.

von Wolff M, Classen-Linke I, Heid D, Krusche CA, Beier-Hellwig K, Karl C \& Bier HM 1999 Tumor necrosis factor - alpha (TNF-alpha) in human emdometrium and uterine secretion: an evaluation by immunohistochemistry, ELISA and semiquantitative RT-PCR. Molecular Human Reproduction 5 146-152.

Wang MY, Rider V, Heap RB \& Feinstein A 1984 Action of antiprogesterone monoclonal antibody in blocking pregnancy after postoital administration in mice. Journal of Endocrinology 101 95-100.

Wincek TJ, Meyer TK, Meyer MR \& Kuehl TJ 1991 Absence of a direct effect of recombinant tumor necrosis factor-alpha on human sperm function and murine preimplantation development. Fertility Sterility 56 332-339. 
Wolf JP, Chilik CF \& Dubois C 1990 Tolerance of perinidatory primate embryos to RU 486 exposure in vitro and in vivo. Contraception 41 85-92.

Wu Y, Tewari M, Cui S \& Rubin R 1996 Activation of the insulin-like growth factor-I receptor inhibits tumor necrosis factor-inducd cell death. Journal of Cell Physiology 168 499-509.

Wuu YD, Pampfer S, Becquet P, Vanderheyden I, Lee KH \& De Hertogh R 1999 Tumor necrosis factor alpha decreases the viability of mouse blastocysts in vitro and in vivo. Biology of Reproduction 60 479-483.

Zar HJ 1999 In Biostatistical analysis, pp 161-176 and 543-558. New Jersey: Princeton Hall Inc.
Zheng M, Cao YQ, lofts B \& Chan ST 1993 A study of protein and glycoprotein synthesis in pre-implantation mouse embryos using mini-2D-electrophoresis, video densitometer scanning and computer-image analysis. Science China B 36 39-44.

Received 20 July 2004

First decision 22 September 2004

Revised manuscript received 25 November 2004

Accepted 16 December 2004 